\title{
Tracking Urban Expansion Using Random Forests for the Classification of Landsat Imagery (1986-2015) and Predicting Urban/Built-Up Areas for 2025: A Study of the Kumasi Metropolis, Ghana
}

\author{
Bernard Fosu Frimpong * and Frank Molkenthin
}

check for updates

Citation: Frimpong, B.F.; Molkenthin, F. Tracking Urban

Expansion Using Random Forests for the Classification of Landsat Imagery (1986-2015) and Predicting Urban/Built-Up Areas for 2025: A Study of the Kumasi Metropolis, Ghana. Land 2021, 10, 44. https:// doi.org/10.3390/land10010044

Received: 12 November 2020 Accepted: 28 December 2020 Published: 5 January 2021

Publisher's Note: MDPI stays neutral with regard to jurisdictional clai$\mathrm{ms}$ in published maps and institutional affiliations.

Copyright: $(2021$ by the authors. Licensee MDPI, Basel, Switzerland. This article is an open access article distributed under the terms and conditions of the Creative Commons Attribution (CC BY) license (https:// creativecommons.org/licenses/by/ $4.0 /)$.
Department of Hydrology, Brandenburg University of Technology, Platz der Deutschen Einheit 1, 03046 Cottbus, Germany; frank.molkenthin@b-tu.de

* Correspondence: BernardFosu.Frimpong@b-tu.de or frimpber@gmail.com

\begin{abstract}
Kumasi is a nodal city and functions as the administrative and economic capital of the Ashanti region in Ghana. Rapid urbanization has been experienced inducing the transformation of various Land Use Land Cover (LULC) types into urban/built-up areas in Kumasi. This paper aims at tracking spatio-temporal LULC changes utilizing Landsat imagery from 1986, 2013 and 2015 of Kumasi. The unique contribution of this research is its focus on urban expansion analysis and the utilization of Random Forest (RF) Classifier for satellite image classification. Change detection, urban land modelling and urban expansion in the sub-metropolitan zones, buffers, density decay curve and correlation analysis were methodologies adopted for our study. The classifier yielded better accuracy compared to earlier works in Ghana. The evaluation of LULC changes indicated that urban/built-up areas are continually increasing at the expense of agricultural and forestlands. The urban/built-up areas occupied 4622.49 hectares (ha) $(23.78 \%), 13,447.50$ ha $(69.18 \%)$ and $14,004.60$ ha (72.05\%) in 1986, 2013 and 2015, respectively of the 19,438 ha area of Kumasi. Projection indicated that urban/built-up areas will occupy 15,490 ha $(79.70 \%)$ in 2025 . The urban expansion was statistically significant. The results revealed the importance of spatial modeling for environmental management and city planning.
\end{abstract}

Keywords: urban/built-up areas; land use land cover; Kumasi; random forest classifier; urban expansion analysis

\section{Introduction}

According to [1], the population of the world is 7.7 billion and it is projected to rise to 8.5 billion in 2030. It is also estimated that, of the extra 2 billion projected population increase from 2019 to 2050, around 1.05 billion (52 per cent) might be added from subSaharan African countries [2]. It has been forecasted that the urban settlers of Sub-Saharan Africa will double between 2000 and 2030 [3]. In West Africa, urban/built-up areas with more than 10,000 dwellers were only 152 in 1950 but rose to 1947 in 2010 [4].

Urbanization plays a major role in affecting human society [5]. It refers to the rise in urban/built-up areas [6]. Rapid urban expansion is regarded as one of the most evident anthropogenic drivers of environmental alterations. It has been earmarked as the key factor responsible for Land Use Land Cover Changes (LULCC) [7]. The non-urban areas are converted to urban/built-up areas to cope with the demands of the growing populations. Several decades of research in LULCC have revealed that Africa will suffer the most consequences of the impacts of LULCC, especially the expansion of urban/built-up areas to the detriment of other LULC types, for example, agricultural and forestlands $[8,9]$.

The urban population is the main problem connected to Africa's rapid urbanization into the natural environment [10]. This growth is partially due to an increase in urban population, migration to the urbanized zones and the reclassification of rural zones as 
urban [11]. Over recent decades, there have been extreme degrees of urban transitional change in megacities in the tropics and subtropics [12].

Ghana's urbanization process can be grouped under three phases, namely: PreColonial (before 1500), Colonial (1500-1956) and Post-Colonial phases (1957 to date) [13]. Despite generations of urban settlements in Ghana, urban life was not characteristic until the middle ages. In the pre-colonial phase, most towns were established in Ghana for economic reasons. A major highlight in the colonial stage was the skewedness of urban expansion. The colonial city Kumasi, for example, became a trade hub and also served administrative purposes [14]. In the post-colonial phase, interventions and policies played a vital part in the clustering of urban/built-up areas of Ghana [15]. The urban population of Ghana was 50.9\% in 2010 and it is projected to reach 70\% in 2050 [16].

Kumasi had a population of 1,730,249 in 2010 which represented 36.2 per cent of its regional population [17]. Urban expansion has been observed due to accelerated economic development. There was a positive interrelationship between population increase and economic activities [16]. There are large zones engaged in automobile repairs, small scale machine manufacturing and trading activities in Kumasi [18]. It has an enormous population growth with an annual growth rate of $5.2 \%$ from 1984 to 2000 and $5.4 \%$ from 2000 to 2010 [19]. Thus, it is one of the most densely populated cities in Ghana and has experienced immense hectares of agricultural and forestlands disappearing [20]. Kumasi has witnessed enormous growth in infrastructure. This intense growth has led to high demand for lands for housing, manufacturing and trading purposes at the detriment of agricultural and forestlands. This phenomenon has led to unplanned and uncontrolled urbanization [21].

Remote Sensing imaging (ground, aerial and satellite) has been utilized to obtain land classification maps for monitoring and analyzing LULC changes [22,23]. Satellite imagery has contributed to studies on the spatial analysis of urban/built-up areas. These satellites include Landsat Thematic Mapper (TM) and Operational Land Imager (OLI) [24-27]. Multitemporal and multi-spectral spatial datasets have proven to be economical and efficient tools for quantifying, monitoring and predicting future land cover change [28,29]. Seminal literature has assessed LULC changes in Kumasi focusing on lost agricultural lands, the extent of LULC and deforestation $[20,30,31]$ and other works have concentrated on the modeling of land use prediction in different cities in Ghana [30,31].

The emergence of potential LULC modeling tools has become a useful technique for forecasting future scenarios of urban/built-up areas [30,31]. The prediction of urban expansion is vital for sustainable land utilization [32]. The Markov Chain was used to predict LULCC in New Juaben in Ghana in the work of [30]. The Multi-Layer Perception (MLP) neural network and the Markov Chain were utilized to forecast LULC for the Greater Accra Metropolitan Area in [31].

Initial work on Kumasi and other cities in Ghana including [20,31,33-38] utilized traditional classifiers for the classification of satellite imageries used in their researches. Hence, it is imperative to improve on the extant literature from the methodological point of view by utilizing the state of the art machine learning Random Forest (RF) classifier to classify satellite images of Kumasi. Therefore, we hypothesize that the RF algorithm produces better classification results compared to previously used traditional classifiers for the study area and other cities in Ghana.

Previous works in Kumasi focused on LULC changes [39], the depletion of urban greenery [40,41]; deforestation and agricultural lands [20,42]; peri-urban trends in Kumasi [43,44]; urbanization and climate [36,45]; and urbanization, land utilization and spatio-environmental impacts [46]. In our research, we focus on the urban/built-up areas of Kumasi. Deeper insights into the urbanization process utilizing different urban analysis techniques were executed at the sub-metropolitan level. We attempt to model and predict a future LULC map for 2025 to serve management purposes for future decision making. Hence, we hypothesize that urban/built-up areas are increasing at the expense of the other LULC classes in Kumasi within the study period. 
This research fills a knowledge gap by employing the RF classifier to extract urban/builtup areas for onward urban expansion analyses in the Kumasi Metropolis. Thus, the objective of this research was to classify LULC utilizing the RF classifier indicating the rates and patterns, predicting urban/built-up areas for 2025 and providing a deeper comprehension of urban expansion in Kumasi.

We hope that our study will act as a reference point and may contribute to the methodological techniques utilized for satellite image classification. It will also be useful for spatial planning to policymakers and other relevant stakeholders in supporting planning and management practices for the future utilization of land in Kumasi.

\section{Materials and Methods}

\subsection{Study Area}

Kumasi has its centre coordinated as latitude $6^{\circ} 42^{\prime} 00.0^{\prime \prime} \mathrm{N}$, longitude $1^{\circ} 37^{\prime} 12.0^{\prime \prime} \mathrm{W}$ and it is about $270 \mathrm{~km}$ north of the capital of Ghana [17]. The city started with a concentric form and spread outwards from areas like Adum, Bompata and Krobo. Kumasi receives an annual mean rainfall of $1484 \mathrm{~mm}$ and has a bimodal rainfall distribution. The Kumasi Metropolitan Assembly (KMA) lies in the transitional forest zone and its major form of cultivation is urban agriculture [17]. The study area covered 10 sub-metropolitan areas with an approximate area of 194.38 square kilometers defined as the Kumasi Metropolis (Figure 1).

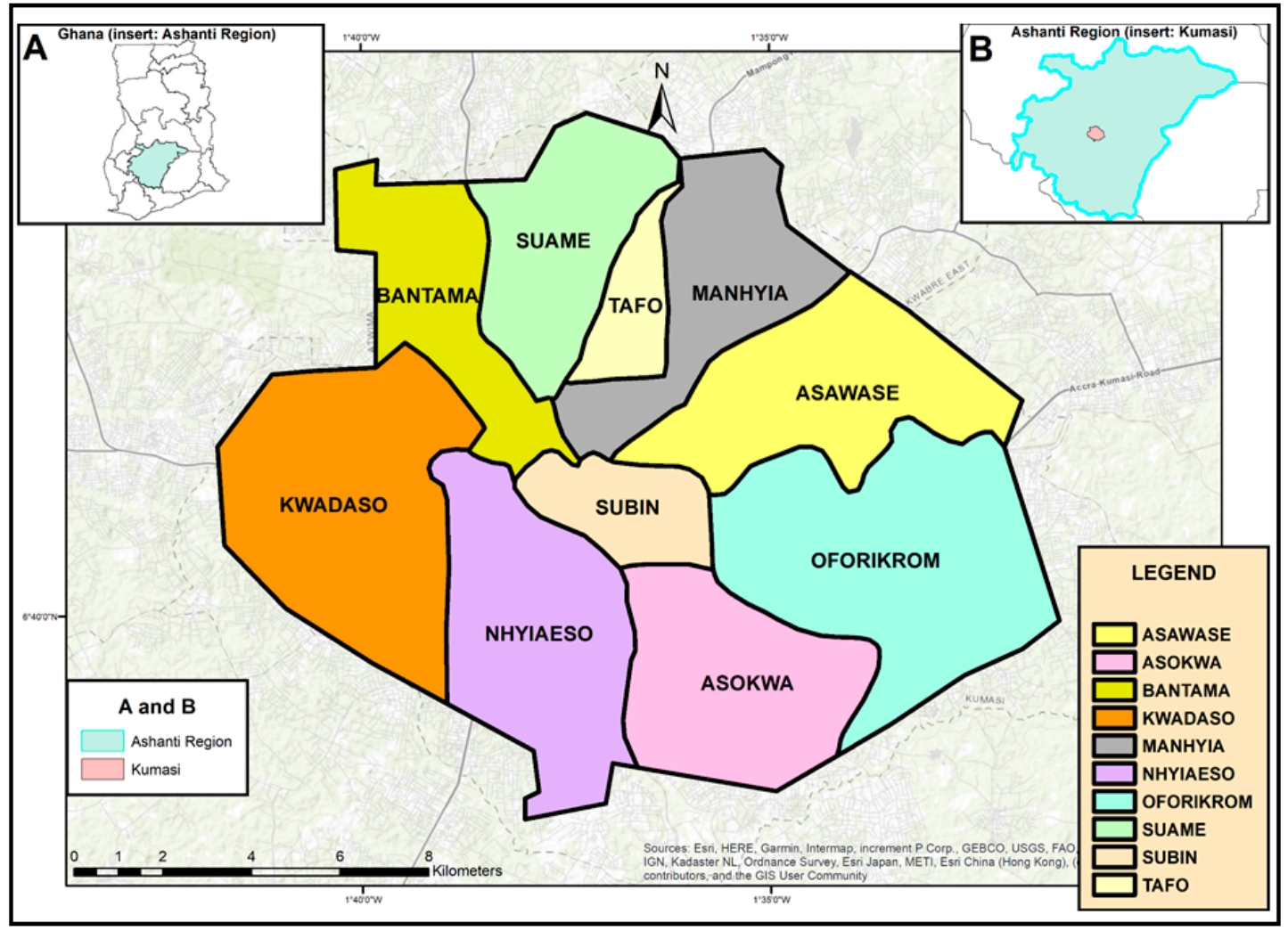

Figure 1. Study Area: Kumasi Metropolis with its sub-metropolitan divisions.

Landsat TM/OLI satellite images were obtained based on availability, suitability, spatial and temporal resolutions as shown in Table 1. The selected images were cloud-free and of the dry season. This explained the differences in the time step of the satellite images utilized in our study. The timespan ranged from 1986 to 2015.

The Landsat and $30 \mathrm{~m}$ Digital Elevation Model (DEM) images were obtained from the Earth Explorer platform of the United States Geological Survey (USGS). The year 2013 was selected because there was massive infrastructural development afterwards within the city that included the construction of the Kumasi Kejetia market in 2014. The Kejetia 
market comprised of 10,000 stores and stalls. This triggered the conversion of forestlands into other land uses. It was relocated to new sites within the city; thus, the idea of using 'before' and 'after' 2014 satellite imagery in our study.

Table 1. Raster Data used in this study.

\begin{tabular}{|c|c|c|c|}
\hline Satellite & Acquisition Date & Number of Bands & Resolution (m) \\
\hline \multicolumn{4}{|l|}{ (a) Landsat Series } \\
\hline Thematic Mapper (TM) -5 & 29.12.1986 & 6 & 30 \\
\hline Operational Land Imager (OLI) -8 & 23.12.2013 & 9 & $30 / 15$ \\
\hline Operational Land Imager (OLI) -8 & 11.01.2015 & 9 & $30 / 15$ \\
\hline $\begin{array}{c}\text { (b) Advanced Spaceborne Thermal Emission } \\
\text { and Reflection Radiometer (ASTER) Global } \\
\text { Digital Elevation Model (GDEM) }\end{array}$ & October 2011 & & 1 arc second approximately $30 \mathrm{~m}$ \\
\hline
\end{tabular}

The ancillary dataset used in the research included the Open Street Map (OSM), World Topographic Map (WTM) and the World Street Maps (WSM). These ancillary maps were cartographically projected to the World Geodetic System (WGS) 84. The OSM road network dataset was downloaded and extracted for Kumasi from the official website of Geofabrik. The WTM and the WSM were embedded as Base maps in the ArcGIS 10.7 (Environmental Systems Research Institute (ESRI)). The updated maps for September 2019 were used which was followed by ground-truthing in January 2020.

The general methodology used for the attainment of the aim of this study is shown in Figure 2.

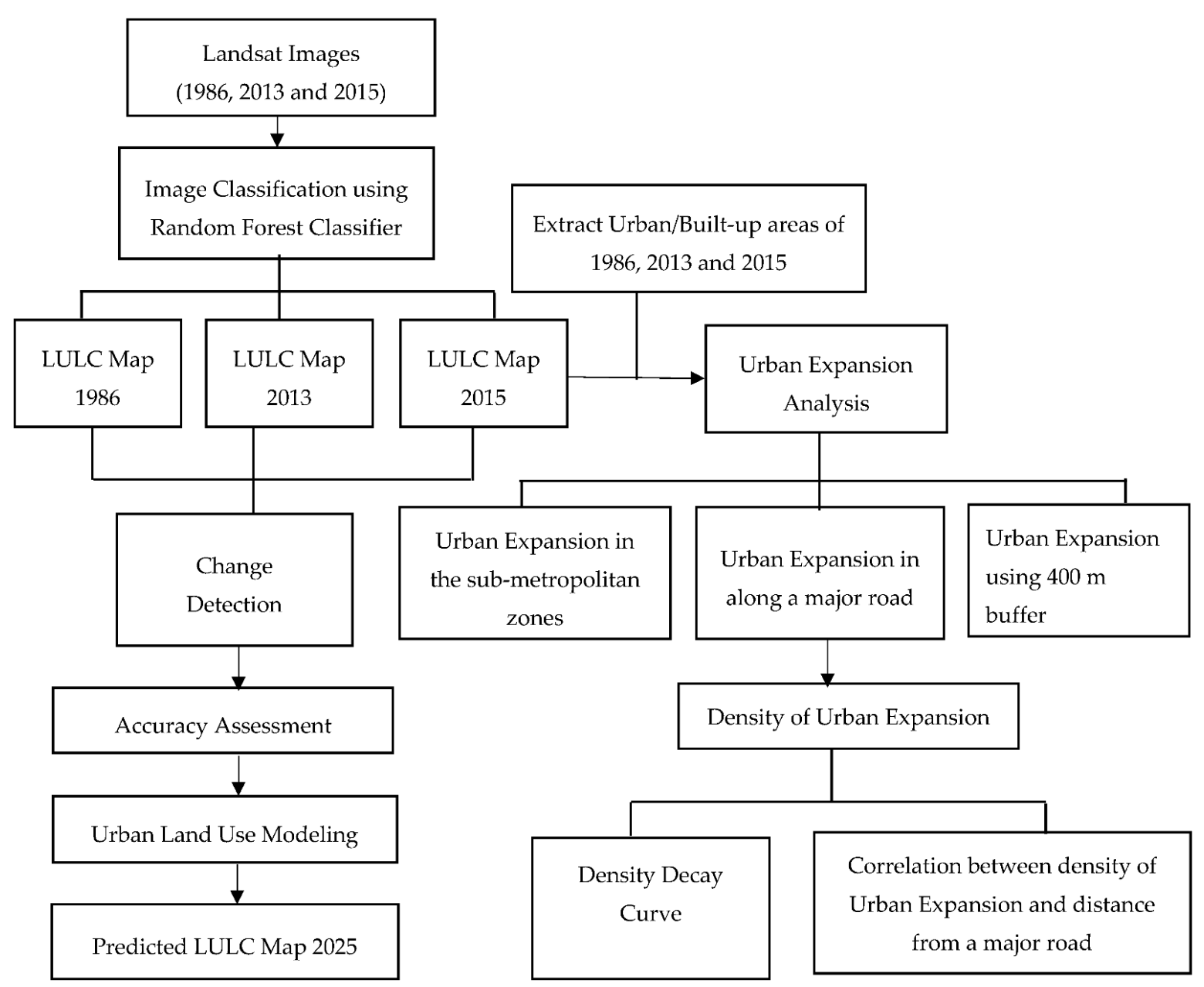

Figure 2. Methodology flowchart adopted for the study. 


\subsection{Satellite Image Processing and Classification}

Landsat images were resampled using the Nearest Neighbor Algorithm. The Nearest Neighbor $(\mathrm{NN})$ resampling method preserved the original values of the original image when compared to other methods [47]. The images were projected using the WGS 84, Universal Transverse Mercator (UTM) Zone $30 \mathrm{~N}$ and Ghana Datum War Office. The area of interest was extracted from the World Topographical Map and the satellite images. The multiple bands (without the thermal and panchromatic bands) were stacked together to obtain a composite band. These operations were carried out in the ArcGIS 10.7.1 environment.

According to [48], three broad LULC types were classified for the selected satellite images based on previous literature on LULC classification in Kumasi [20,42]. The classes were urban/built-up areas, agricultural, and forestlands. A concise description of the classes is illustrated in Table 2.

Table 2. LULC Classes.

\begin{tabular}{|c|c|c|}
\hline LULC Category & Description & \\
\hline \multirow{4}{*}{ Urban/Built-up Areas } & Residential & Commercial \\
\hline & Industrial & Power and communications facilities \\
\hline & Institutions & Highways and Transportation \\
\hline & Lands with exposed soil surface & \\
\hline \multirow{2}{*}{ Agricultural Lands } & Cropland & Pasture \\
\hline & Horticultural Areas & \\
\hline Forestlands & \multicolumn{2}{|c|}{$\begin{array}{l}\text { Mixed Forestlands: short canopy trees of about } 5-10 \mathrm{~m} \text { high with a thin occurrence of } \\
\text { some emergent trees }\end{array}$} \\
\hline
\end{tabular}

Supervised classification was used for the identification, classification and evaluation of the LULC types. The Random Forest Algorithm was utilized to assign pixels to their respective classes since RF is not limited by statistical assumption [49]. The satellite image classification was executed in the ArcGIS 10.7.1 environment.

\subsection{Accuracy Assessment}

The training samples representing the LULC types were evaluated especially for the 2015 Landsat satellite imagery. The ground control points totaled 150, comprising of 50 ground control points for each class (urban/built-up areas, agricultural and forestlands). This was evaluated and validated using GPS etrex 64s. The Open Street Map dataset, World Topographic Map, World Street Map and Google Earth Historical Imagery were referenced to aid in the identification of the LULC classes.

\subsection{Urban Land Modeling and Validation}

The Landsat images were initially checked to ensure the images were harmonized, and had the same spatial characteristics, legend and consistent categories. The temporal images of 1986 and 2013 were used as the base maps. The initial step was the change analysis. This was assessed between $\boldsymbol{t} \mathbf{1}$ and $\boldsymbol{t} \mathbf{2}$ of the two LULC maps. The 'from-to' identified the transitions from a particular LULC type to another. The drivers of urban expansion considered were slope, elevation, distance to urban/built-up areas and distance to a main road. These were selected based on a review of previous studies [30,50].

The slope and elevation were extracted from the Digital Elevation Model and were incorporated to account for the geophysical factors. In 1986, the distance to urban/builtup areas was set as a dynamic variable. The distance to urban variable indicated the closeness of pixels to existing urban/built-up areas in 2013. The modeling of the distance to urban/built-up areas was set up as a dynamic variable which indicated that the distance to urban pixels change with time.

The Multi-Layer Perceptron (MLP) was utilized in the modeling process. The neural network was trained to build a model utilizing the information obtained from the data. 
This was to enable the network to hypothesize and forecast the outputs. The weights were defined in the training phase before the prediction. The error in the network was reduced by adjusting the weights between the nodes (using a proportion of the input data), using the backpropagation algorithm. After iterations, the calculation of the error that spread across the neural network was done. The model was trained using sample pixels that experienced transitions from one land-use type to another, and the pixels that remained unchanged in the two LULC maps. The sample size was equivalent to the least number of pixels that changed from one land-use type to another. The chosen pixels were assigned to two groups; one group to train the model and the other group to test or validate the accuracy of the model.

Markov Chain Analysis was used to model the quantitative alterations in each transition for the projected year (2025). The Markov chain was multi-directional and a specific LULC was theoretically changed into or from other LULC [51]. The change analyses and the transition potential maps produced were used to forecast the future scenario for 2015. The predicted map with the same LULC categories as the input maps was generated.

Validation enabled the determination of the quality of the forecasted map for 2015 compared to the real 2015 LULC map. Visual and statistical approaches were used in the validation of the models [52]. This resulted in a map consisting of four major groups:

i 'Hits' meant the changes in the predicted model were correct.

ii 'False alarms' signified the model predicted changes but remained unchanged.

iii 'Misses' indicated the model predicted no changes, but changes occurred.

iv 'Null success' meant the model predicted no changes and remained stable.

Finally, after verification, the predictive ability of the model was assessed. Simulation was done to forecast the LULC map for 2025 utilizing the 2013 and 2015 LULC maps as the base maps. The entire procedure was repeated to obtain the projected map of 2025. Urban land modeling and validation were executed using the Terrset software.

\subsection{Urban Expansion Analysis}

The urban/built-up areas were extracted from the satellite imagery to analyze the rate and pattern of urban expansion. Overlays were done to generate the general overview of urban/built-up areas and in the various sub-metropolitan zones.

The process of urban expansion showed a relation to geographic features such as roads. It was evident that trade and commerce were rudimentary reasons for the establishment of cities in Ghana. For instance, markets, banks and other service providers set up their firms in proximity to major roads in Ghana [14] as high capacity urban roads face larger amounts of land use and urban expansion [53]. Again, it is asserted that proximity to major roads is a vital factor for urban expansion in the works of [54-56] on Hangzhou in China, North-Eastern Ohio Region in the United States of America, and Sekondi-Takoradi in Ghana. This situation was synonymous with that in Kumasi. The research, therefore, adopted this strategy to investigate urban expansion along the Kumasi-Accra road. The stretch of this road was $19 \mathrm{~km}$ in the study area. This road was chosen as it has high prominence in Ghana and lies in the urban/built-up areas in Kumasi.

The urban expansion maps were converted from raster format into a vector form and were overlaid with the Kumasi-Accra road. Within a $4 \mathrm{~km}$ buffer, a $400 \mathrm{~m}$ buffer interval was used. This research utilized the $400 \mathrm{~m}$ interval buffer based on previous literature [56] and was also adopted as a pragmatic approach. The buffers were commutatively created around the Kumasi-Accra road. Each of the buffers invented was overlaid with the urban expansion feature to compute total urban expansion present in each buffer. These map conversions and buffer creation operations were executed using the ArcGIS 10.7.1 software.

\subsection{Density of Urban Expansion}

This was computed to ascertain how dense the urban/built-up areas are in each of the created buffers and was used in the overall computation of the density decay function. 
The Density of Urban Expansion in each buffer zone was computed using the formula as adopted from [56];

$$
\text { Density of Urban Expansion }=\frac{\text { Amount of Urban Expansion in each buffer zone }}{\text { Total amount of land in each buffer zone }}
$$

To establish the correlation between the density of urban expansion and the distance to the main Kumasi-Accra road, the density decay function was composed, which aided in analyzing the expansion of the urban/built-up areas in Kumasi.

Correlation between Density of Urban Expansion and Distance to the Main Road

The relationship between the density of urban expansion and the distance to a major road was investigated using Pearson's Correlation Analysis [56]. The Pearson coefficient of correlation was computed for the ten buffer zones using the formula;

$$
r=\frac{\sum X Y-\frac{\sum X \sum Y}{N}}{\sqrt{\left(\sum X^{2}-\frac{\left(\sum X^{2}\right)}{N}\right)\left(\sum Y^{2}-\frac{\left(\sum Y\right)^{2}}{N}\right)}}
$$

where:

$\mathrm{r}=$ Correlation coefficient

$\mathrm{X}=$ Distance to the main road (Kumasi-Accra road)

$\mathrm{Y}=$ Density of Urban Expansion

$\mathrm{N}=$ total buffers

The significance of the correlation ' $r$ ' was tested at a statistical significance of $5 \%$.

\subsection{Software Used}

ArcGIS 10.7.1 was employed to assess image accuracy and analyze urban expansion. The change detection was executed using the Terrset software. The correlation and the general visualization of graphs were done using Matlab R2020a.

\section{Results}

\subsection{General Description and LULC Distribution}

In the classified image of 1986, the central portions of the city were the urban/built-up areas; however, most of the area was covered by forestlands. The urban/built-up areas were surrounded by portions of agricultural lands. However, in the classified image of 2013, most portions located in the peripheries of Kumasi were covered by urban/built-up areas. Visually, the forestlands had decreased the most. The 2015 classified image had almost all the boundaries transformed into urban/built-up areas. Nevertheless, it had small clusters of forestlands within the metropolis.

The LULC distribution revealed that forestlands occupied the largest area in 1986. However, there was a drastic decrease in 2013 and 2015 in terms of hectares. Agricultural lands which occupied a small area in 1986 increased in both 2013 and 2015 (Figure 3).

It was interesting that the urban/built-up area that occupied less than a quarter of the city had expanded in 2013 with a percentage increase of (45.40\%). Again, there was a significant increase of $3.43 \%$ in the period (2013-2015). The single most striking observation was the percentage decrease in forestlands throughout the study. There was $(-58.65 \%)$ and $(-6.29 \%)$ reduction for the periods (1986-2003) and (2003-2015) respectively (Table 3). 
(a) LULC 1986

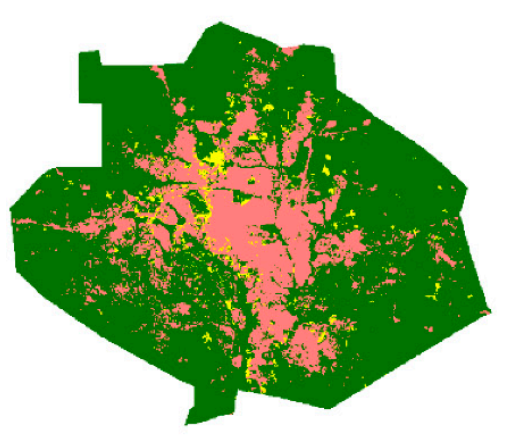

(b) LULC 2013

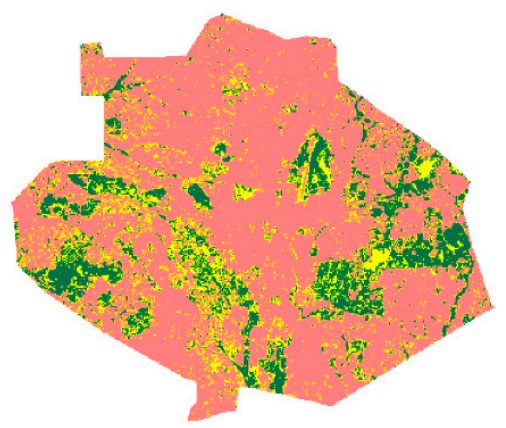

Legend

Urban/Built-Up

Agricultural Lands

Forestlands (c) LULC 2015

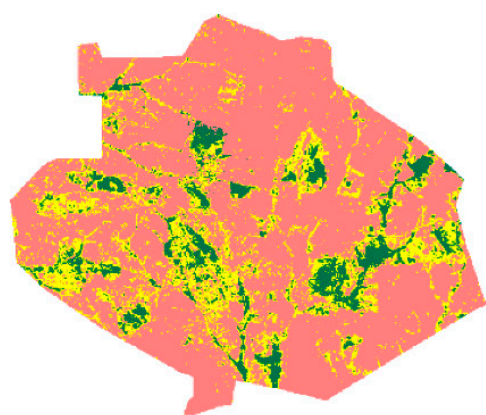

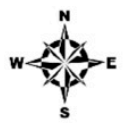

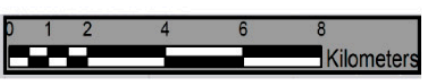

Projection:

UTM Zone $30 \mathrm{~N}$

Datum: WGS 84

Figure 3. Land Use Land Cover (LULC) maps for the years 1986, 2013 and 2015.

Table 3. Distribution of LULC.

\begin{tabular}{ccccccc}
\hline \multirow{2}{*}{ LULC Categories } & \multicolumn{2}{c}{1986} & \multicolumn{2}{c}{$\mathbf{2 0 1 3}$} & \multicolumn{2}{c}{$\mathbf{2 0 1 5}$} \\
\cline { 2 - 7 } & Area (ha) & Area (\%) & Area (ha) & Area (\%) & Area (ha) & Area (\%) \\
\hline Urban/built-up & 4622.49 & 23.78 & $13,447.50$ & 69.18 & $14,004.60$ & 72.05 \\
Agricultural lands & 716.40 & 3.69 & 3292.92 & 16.94 & 3959.01 & 20.37 \\
Forestlands & $14,098.90$ & 72.53 & 2697.30 & 13.88 & 1474.11 & 7.58 \\
TOTAL (ca.) & 19,438 & 100 & 19,438 & 100 & 19,438 & 100 \\
\hline
\end{tabular}

The annual rate of change recorded high percentages for agricultural lands and urban/built-up areas. However, forestlands diminished the most, reducing consistently during the entire period. This indicated that urban/built-up areas were increasing to the detriment of the other LULC types (Table 4).

Table 4. Changes in Area and Percentages.

\begin{tabular}{ccccccc}
\hline \multirow{2}{*}{$\begin{array}{c}\text { Land Use Land } \\
\text { Cover Categories }\end{array}$} & \multicolumn{2}{c}{ 1986-2013 } & \multicolumn{2}{c}{ 2013-2015 } & \multicolumn{2}{c}{ Annual Rate of Change (\%) } \\
\cline { 2 - 7 } & Area (ha) & Percentage Change (\%) & Area (ha) & Percentage Change (\%) & $\mathbf{1 9 8 6 - 2 0 1 3}$ & 2013-2015 \\
\hline Urban/built-up & 8825.0 & 45.4 & 557.1 & 2.9 & 1.7 & 1.4 \\
Agricultural & 2576.5 & 13.3 & 666.1 & 3.4 & 0.5 & 1.7 \\
$\quad$ lands & $-11,401.6$ & -58.7 & -1223.2 & -6.5 & -2.2 & -3.3 \\
Forestlands & - & &
\end{tabular}

\subsection{Nature of LULC Changes}

The nature of changes was considered as stable (areas with no change or which were persistent) and unstable (loss or gain by each class). From 1986 to 2013, there was an increased urban/built-up expansion. Thus, there were changes in agricultural and forestlands. Forestlands depleted the most compared to urban/built-up areas and agricultural lands.

For the areal changes between 2013 and 2015, the visual inspection indicated traceable changes. The urban/built-up areas were persistent. The most prominent changes were obtained between forestlands and agricultural lands (Figure 4). 
(a) Areal Changes 1986 - 2013

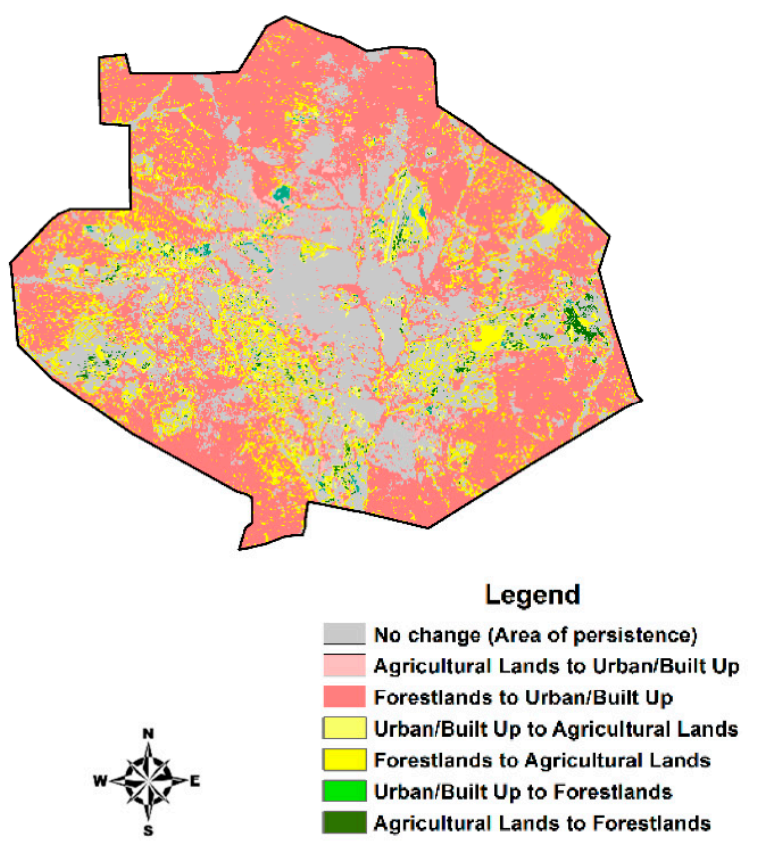

(b) Areal Changes $2013-2015$

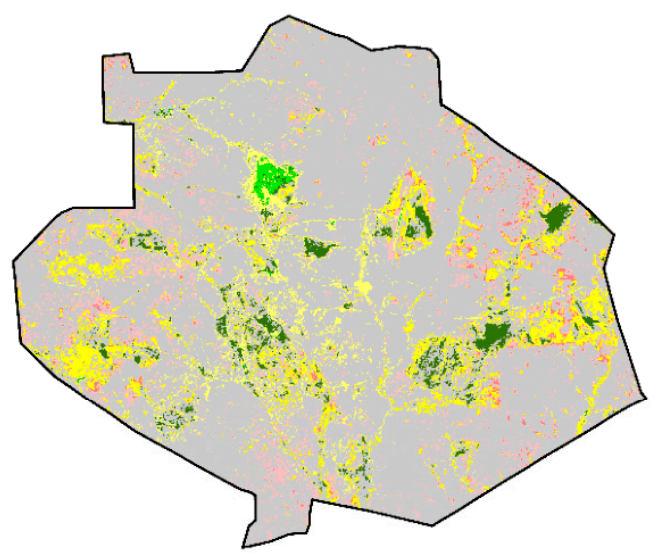

Projection:

UTM Zone 30N

Datum: WGS 84

Figure 4. Change Map showing transition of LULC.

\subsection{Tabulation of LULC Changes}

The area of persistence for the initial phase (1986 to 2013) was 6673.32 ha representing $34.3 \%$ of the entire area of Kumasi. Forestlands experienced the highest instability losing 9197.10 ha and 2586.87 ha to urban/built-up and agricultural lands, respectively. In all, urban/built-up areas increased most whilst the forestlands were drastically diminished.

However, from 2013 to 2015, the area of stability was $14,642.90$ ha representing $75.3 \%$ of the total area. The usual trend noticed was that forestlands were transformed into agricultural lands. Agricultural lands were also transformed into urban/built-up areas (Table 5).

Table 5. Change analysis of the area of change from 1986 to 2015.

\begin{tabular}{ccc}
\hline Land Use Land Cover Change & \multicolumn{2}{c}{ Areal Extent (in Hectares) } \\
\cline { 2 - 3 } & $\mathbf{( 1 9 8 6 - 2 0 1 3 )}$ & $\mathbf{( 2 0 1 3 - 2 0 1 5 )}$ \\
\hline No change & 6673.32 & $14,642.90$ \\
Agricultural Lands to Urban/built-up & 253.17 & 1304.28 \\
Forestlands to Urban/built-up & 9197.10 & 255.69 \\
Urban/built-up to Agricultural Lands & 457.65 & 1045.08 \\
Forestlands to Agricultural Lands & 2586.87 & 1584.72 \\
Urban/built-up to Forestlands & 200.34 & 80.10 \\
Agricultural Lands to Forestlands & 69.30 & 524.97 \\
\hline Total Area (ca.) & $19,438.00$ & $19,438.00$ \\
\hline
\end{tabular}

\subsection{Accuracy Assessment}

The RF algorithm produced kappa statistics for 1986, 2013 and 2015 as 86\%, 96\% and $97 \%$, respectively. The user and producer accuracies are elaborated in Appendix A.

\subsection{LULCC Models and Validation}

The urban/built-up area as the major transition model studied and as such the vital transitions from other land use classes were explored. Cramer's V indicated the potential 
explanatory strength of a driving factor in urban expansion. According to [57], a Cramer's $\mathrm{V}$ value of 0.15 and above for any driving factor was considered very valuable, whilst a value greater than or equal to 0.4 was good (Table 6).

Table 6. Values for Cramer's V.

\begin{tabular}{cc}
\hline Driving Force & Cramer's V \\
\hline Distance from roads & 0.270 \\
Distance from Urban & 0.150 \\
Elevation & 0.002 \\
Slope & 0.012 \\
\hline
\end{tabular}

\subsection{Validated and Projected Maps}

Figure 5a depicts the validated projection of the LULC map for 2015 illustrating the accuracy accomplished by the model. The maps were composed of 'null success', 'false alarms', 'misses' and 'hits'. The visualization revealed that 'null success' dominated. However, false alarms were seen widely in the validated map.

Figure $5 b$ shows the projected LULC for the year 2025. The dominant class for the projected map was urban/built-up areas. Agricultural lands were predicted to occupy higher portions compared to the smaller portions they once occupied.

(a) Validated LULC Map for Kumasi 2015
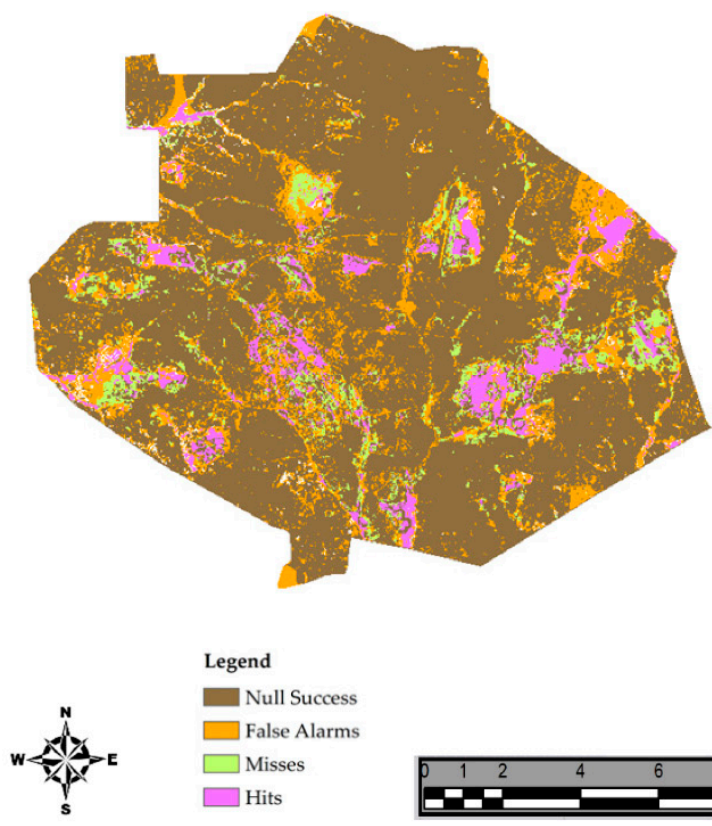

(b) Projected LULC Map for Kumasi 2025

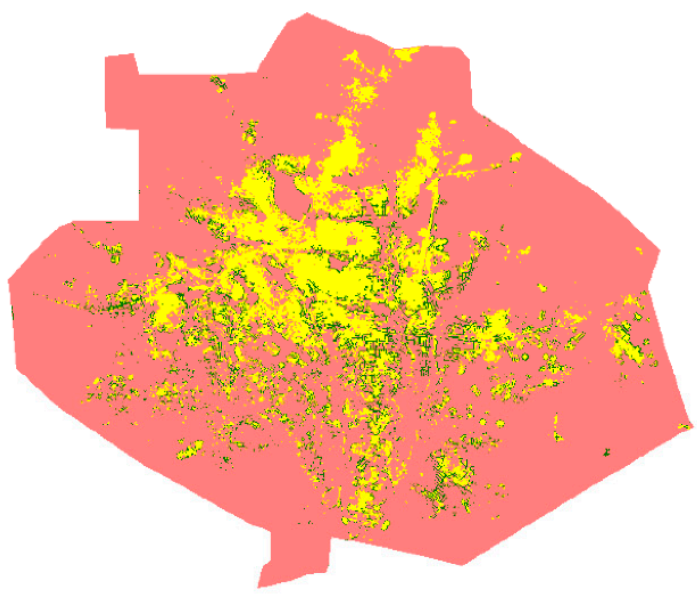

Projection:

UTM Zone $30 \mathrm{~N}$

Datum: WGS 84

Figure 5. Validated and Projected maps.

\subsection{Areal Extent of each LULC in 2025}

Urban/built-up areas are projected to cover 15,490.98 ha representing $79.70 \%$ of the entire area. The urban/built-up areas will increase by $7.65 \%$ from 2015 to 2025 . Agricultural lands are also tipped to occupy 3038.98 ha $(15.63 \%)$. However, forestlands are expected to cover 908.83 ha $(4.67 \%)$ in 2025 (Figure 6). 


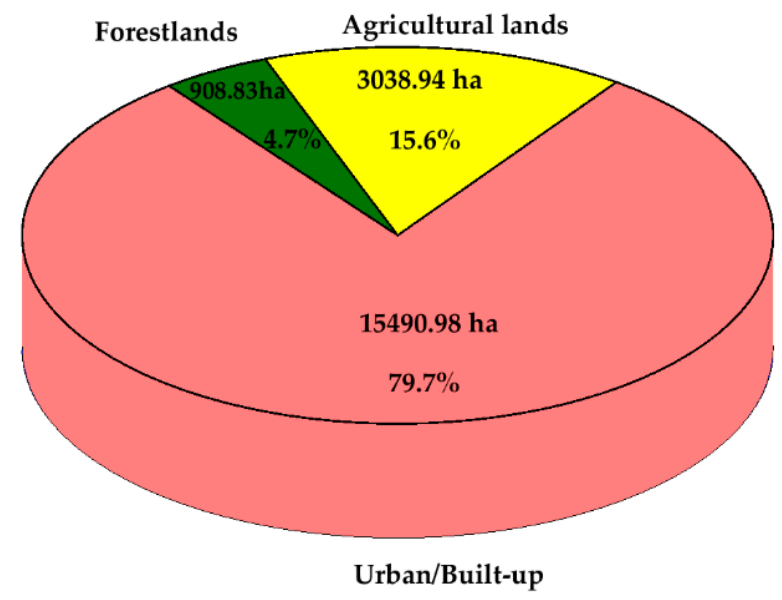

Figure 6. Projected LULC distribution for 2025.

\subsection{Urban Expansion Analysis}

The overlays showed the extent of spatial expansion that occurred over the study period. There was an increasing pattern in terms of the spread of the urban/built-up areas from 1986 to 2015 (Figure 7).

(a) Urban 1986
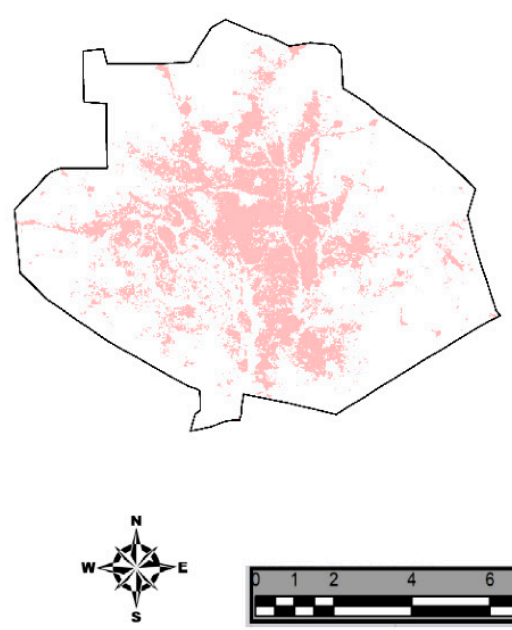

(b) Urban 2003

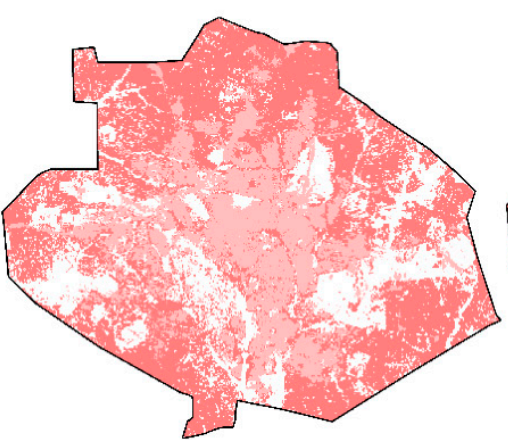

Legend

Urban/Built-Up 1986 Urban/Built-Up 2013 Urban/Built-Up 2015 (c) Urban 2015

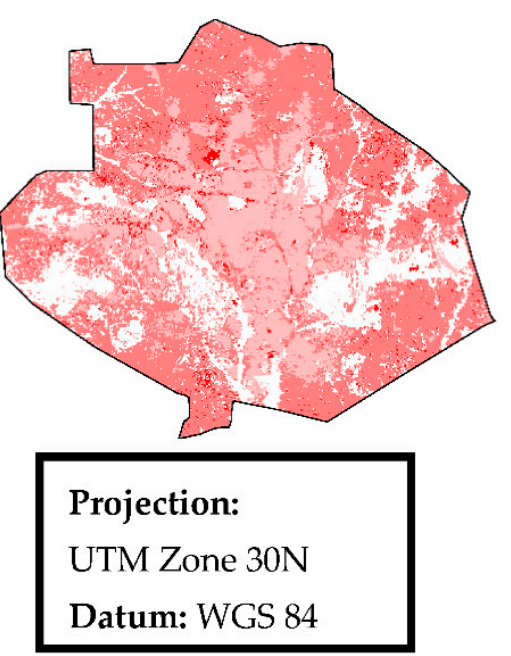

Figure 7. Urban expansion in Kumasi.

\subsection{Urban Expansion in the Sub-Metropolitan Zones}

Urban expansion was very evident in all the sub-metropolitan zones. This pattern of urban expansion can therefore be expressed as ubiquitous. This urban extent was found extensively on the peripheries of the various zones (Figure 8). 


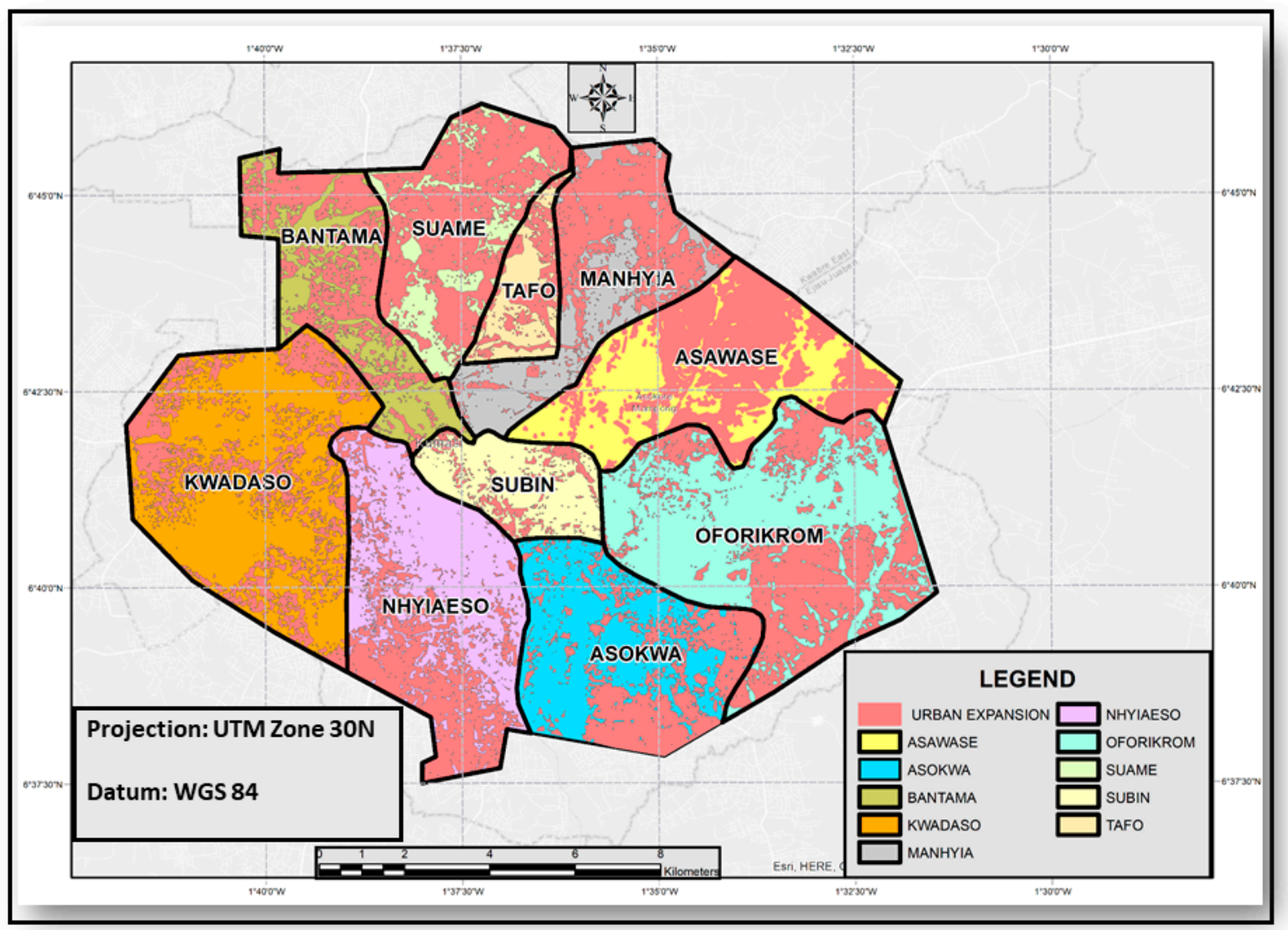

Figure 8. Urban expansion in sub-metropolitan areas.

\subsection{Urban Extent in each Sub-Metropolitan Area in Kumasi}

Urban area covered 4692 ha, 13,489 ha and 13,937 ha for 1986, 2013 and 2015, respectively. Urban/built-up areas increased by 45.4\% from 1986 to 2013, and from 2013 to 2015 urban/built-up areas increased by $2.87 \%$. The urban/built-up areas rose from 4622.49 ha in 1986 to $13,447.50$ ha in 2013 and finally to $14,004.60$ ha in 2015. In 1986, Asokwa yielded the highest urban extent (729.36 ha) and the least value was recorded for Bantama (286.56 ha). Subsequently, the urban extent of Oforikrom was the highest with 2039.59 ha and 2129.94 ha in 2013 and 2015, respectively. Tafo produced the least with 512.10 ha in 2013 and 517.59 ha in 2015 . All zones revealed consistent increment in urban zones throughout the study period (Table 7).

Table 7. Urban Extent in each sub-metropolitan area.

\begin{tabular}{|c|c|c|c|c|c|c|}
\hline \multirow[b]{2}{*}{$\begin{array}{c}\text { Sub- } \\
\text { Metropolitan }\end{array}$} & \multicolumn{2}{|c|}{1986} & \multicolumn{2}{|c|}{2013} & \multicolumn{2}{|c|}{2015} \\
\hline & $\begin{array}{l}\text { Urban Extent } \\
\text { (ha) }\end{array}$ & $\begin{array}{c}\text { Urban } \\
\text { Extent } \\
(\%)\end{array}$ & $\begin{array}{c}\text { Urban Extent } \\
\text { (ha) }\end{array}$ & $\begin{array}{c}\text { Urban Extent } \\
(\%)\end{array}$ & $\begin{array}{l}\text { Urban Extent } \\
\text { (ha) }\end{array}$ & $\begin{array}{c}\text { Urban Extent } \\
(\%)\end{array}$ \\
\hline Asawase & 498.78 & 10.63 & 1397.52 & 10.36 & 1596.33 & 11.45 \\
\hline Asokwa & 729.36 & 15.54 & 1547.64 & 11.47 & 1563.03 & 11.21 \\
\hline Bantama & 286.56 & 6.11 & 1157.84 & 8.58 & 1165.86 & 8.37 \\
\hline Kwadaso & 421.74 & 8.99 & 1666.00 & 12.35 & 1768.65 & 12.69 \\
\hline Manhyia & 583.65 & 12.44 & 1504.80 & 11.16 & 1518.66 & 10.90 \\
\hline Nhyiaeso & 470.79 & 10.03 & 1578.60 & 11.70 & 1580.49 & 11.34 \\
\hline Oforikrom & 500.13 & 10.66 & 2039.59 & 15.12 & 2129.94 & 15.28 \\
\hline Suame & 302.67 & 6.45 & 1395.26 & 10.34 & 1398.33 & 10.03 \\
\hline Subin & 586.26 & 12.50 & 689.22 & 5.11 & 698.16 & 5.00 \\
\hline Tafo & 312.12 & 6.65 & 512.10 & 3.80 & 517.59 & 3.71 \\
\hline TOTAL (ca) & 4692 & 100 & 13,489 & 100 & 13,937 & 100 \\
\hline
\end{tabular}




\subsection{Urban Expansion along a Major Road}

Along the $19 \mathrm{~km}$ stretch of the Kumasi-Accra road, it was clear that urban/built-up areas extended throughout the entire buffers. The urban/built-up areas were sparsely distributed on the western part of the created buffers. Urban expansion covered 33.8\% and was found within $2 \mathrm{~km}$ from the Kumasi-Accra road in the $400 \mathrm{~m}$ buffer. The major expansion of urban/built-up areas was clustered directly on opposite sides of the created buffers (in the north-south) (Figure 9).

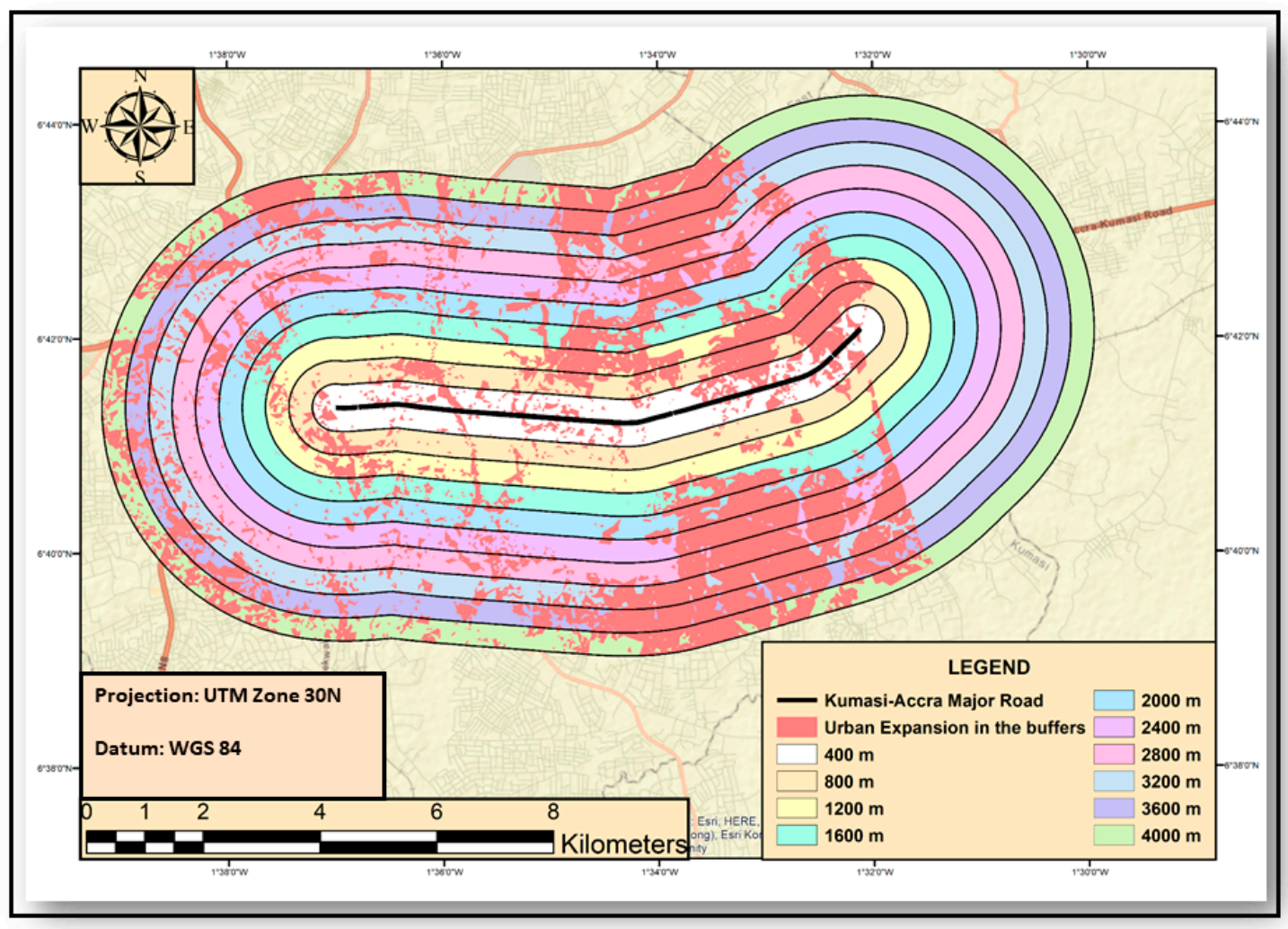

Figure 9. Urban expansion (400 m) along the main Kumasi-Accra Road.

\subsection{Urban Expansion in the 400 Meters Buffer}

The buffer values ranged from 153.30 ha to 3086.23 ha. The highest difference was recorded for buffers between $3200 \mathrm{~m}$ and $3600 \mathrm{~m}$ as $512.67 \mathrm{ha}$. However, the least urban measure was recorded for the buffer in between $400 \mathrm{~m}$ and $800 \mathrm{~m}$. The $4000 \mathrm{~m}$ buffer had the highest urban percentage of $24.54 \%$ and the least was recorded in the $400 \mathrm{~m}$ buffer with $18.78 \%$ (Table 8 ).

Table 8. Urban, total area and percentage urban in buffers.

\begin{tabular}{cccc}
\hline Buffer (m) & Area of Urban Expansion in Each Buffer (ha) & Total Land Size in Each Buffer (ha) & Percentage Urban (\%) \\
\hline 400 & 153.30 & 816.28 & 18.78 \\
800 & 368.62 & 1721.93 & 21.41 \\
1200 & 606.58 & 2524.41 & 24.03 \\
1600 & 817.71 & 3834.06 & 21.33 \\
2000 & 1041.62 & 5040.65 & 20.66 \\
2400 & 1328.26 & 6347.90 & 20.92 \\
2800 & 1634.95 & 7755.11 & 21.08 \\
3200 & 2025.79 & 9262.61 & 21.87 \\
3600 & 2574.46 & $10,870.33$ & 23.68 \\
4000 & 3086.23 & $12,578.35$ & 24.54 \\
\hline
\end{tabular}




\subsection{Density of Urban Expansion}

The values ranged from 0.19 to 0.25 . An increasing trend was observed before the $2000 \mathrm{~m}$ buffer. The value for the density of urban expansion reduced by 0.01 in the buffers of $2000 \mathrm{~m}$ and $2400 \mathrm{~m}$. However, it increased from the $2800 \mathrm{~m}$ until the $4000 \mathrm{~m}$ buffer. The density of urban expansion revealed an increasing trend from the $2400 \mathrm{~m}$ to the $4000 \mathrm{~m}$ buffer which also showed a rising pattern in urban/built-up areas (Table 9).

Table 9. Density of urban expansion.

\begin{tabular}{cc}
\hline Buffer $(\mathbf{m})$ & Density of Urban Expansion \\
\hline 400 & 0.19 \\
800 & 0.21 \\
1200 & 0.22 \\
1600 & 0.21 \\
2000 & 0.20 \\
2400 & 0.20 \\
2800 & 0.21 \\
3200 & 0.22 \\
3600 & 0.24 \\
4000 & 0.25 \\
\hline
\end{tabular}

\subsection{Density Decay Curve}

The relationship between the Kumasi-Accra road and the density of urban expansion was depicted in the density decay curve (Figure 10). There was also a gradual rise until $1200 \mathrm{~m}$. The value dropped in the $1600 \mathrm{~m}$ buffer and remained steady till the $2400 \mathrm{~m}$ buffer. The curve revealed an increasing trend until $4000 \mathrm{~m}$. The mathematical expression of the relationship between the distance to the Accra-Kumasi road and the density of urban expansion is expressed as;

$$
y=0.0041 x+0.19
$$

where

$\mathrm{y}=$ density of urban expansion

$\mathrm{x}=$ distance to $\mathrm{a}$ major road

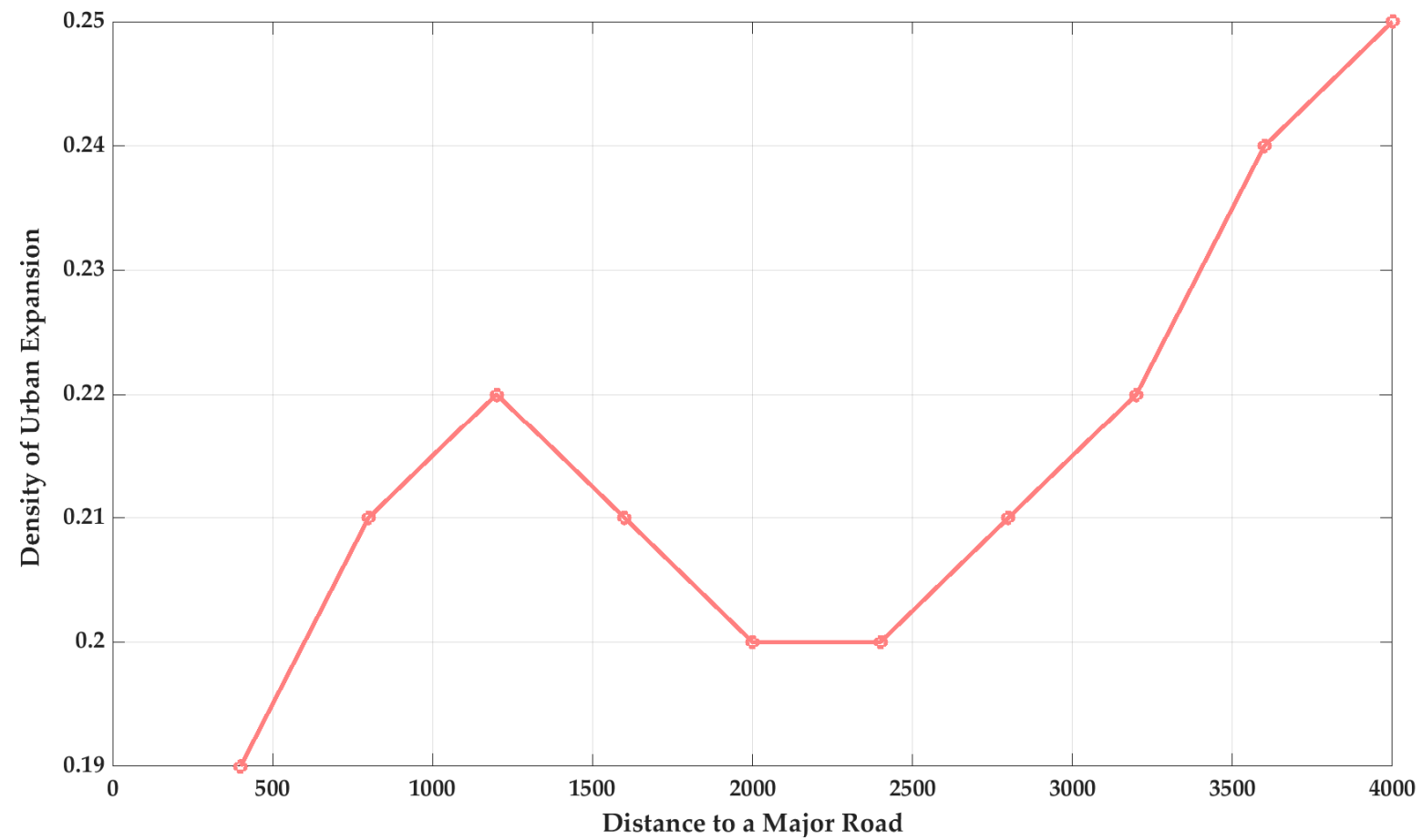

Figure 10. Density Decay Curve. 


\subsection{Correlation between Density of Urban Expansion and Distance to the Kumasi-Accra Road}

There was a high positive correlation in the buffers along the Kumasi-Accra road. The direct and strong correlation of 0.75 indicated an increase in urban expansion, with increasing size in the buffer. The student $t$-test revealed that the urban expansion using the $400 \mathrm{~m}$ buffer was significant (Appendix B).

\section{Discussion}

\subsection{Image Classification and Accuracy Assessment}

Research has explored the classification accuracies amongst the state of the art machine learning classifiers. Random Forest outperformed Artificial Neural Networks (ANNs) classifiers in the work of [58], and Linear Discriminant Analysis [59]. The kappa statistics, user and producer accuracies also produced satisfactory results in our research. The accuracies were higher compared to accuracies produced in the works of [20,37-39] for Kumasi and other parts of Ghana. The higher accuracy results obtained in this research could be attributed to the use of the machine learning algorithm, RF classifier. The performance of the RF in this research was in agreement with the findings of $[58,59]$ that discussed the robustness and the computational efficiency of RF over other satellite image classifiers.

\subsection{Land Use Land Cover Changes}

Urban/built-up areas have been put under intense pressure [21,43]. An urban/builtup area is considered economically rewarding in comparison to agricultural and forestlands, accounting for accelerated land conversion from agricultural lands to urban/built-up areas [60]. This research confirmed that agricultural and forestlands were transformed into residential areas, public places, roads and industries [43,44,61]. In Sekondi-Takoradi (the third largest city in Ghana in terms of population) [62], a substantial amount of agricultural land was reduced and transformed into urban/built-up areas. Urban/built-up areas have doubled over the other land-use types [25], as consistently found in this research.

\subsection{Causes of LULC Changes}

The population of Kumasi was 469,628 in 1984. However, in the 2000 population census, Kumasi had 1,170,270 inhabitants. In the last census of 2010, Kumasi recorded a population of 1,730,249. It can be inferred from the years 1984, 2000 and 2010 that the population has increased tremendously. The rise in urban population from 2000 to 2010 was $48 \%$ [62]. Thus, it can be inferred that urban expansion to accommodate the increasing population was the main factor responsible for the changes in LULC.

Kumasi serves as the economic hub of the middle belt of Ghana. This has led to high demand for housing facilities [19]. There is a high in-migration of people into Kumasi, and the prominent motives being for trading and employment purposes. The lateral pattern of expansion in the sub-metropolitan zones shows that people are eager to acquire lands and construct housing facilities to accommodate the booming population in the Kumasi Metropolis [19,21,44].

The reduction in agricultural and forestlands could be attributed to inadequate and weak policy regimes. Although there are regulations in place, enormous illegal development has happened in Kumasi. The reasons for this uncontrolled urban expansion could partly be blamed on the compromised enforcement of laws [63]. The biggest challenges relating to Ghana's laws and regulations are related to enforcement and compliance. There is laxity in the enforcement of laws regarding land use in Ghana [63]. This relaxation of the laws could account for the losses in the natural landscape.

\subsection{Urban Expansion in Kumasi}

Urban expansion was ubiquitous in the ten sub-metropolitan zones. The areas close to the periphery were initially covered with agricultural and forestlands. This indicated that land developers and individuals are eager to transform the other LULC types into urban/built-up areas (Figure 7). We found that, in the $2 \mathrm{~km}$ buffer, the urban extent 
represented $66.2 \%$ which is indicative of rapid urban expansion in Kumasi. The buffer of $400 \mathrm{~m}$ showed a positive correlation between the density of urban expansion and the distance to the main road meaning that the farther away from the Kumasi-Accra main road, the higher the density of urban expansion. This positive correlation was comparable to the work of [56] in the Sekondi-Takoradi Metropolis in Ghana.

It was observed that the non-urban areas have been transformed into urban/built-up areas as the size of the buffer increased. The density of urban expansion was synonymous with the density decay curve with both revealing an increase in trend in urban/built-up areas. This partly explains the increased urban expansion in Kumasi. This pattern is attributed to the fact that most of the social amenities are near the highway. Developers in the city develop sites close to the highway to take full advantage of the available infrastructure and social amenities. This outcome supported the earlier assertion made by [23] that agricultural lands were the first to be transformed into urban/built-up areas.

Urban expansion was significantly experienced towards the periphery of the submetropolitan zones. The highest urban expansion in the Oforikrom sub-metropolitan zone could be attributed to the presence of many academic institutions that include the Kwame Nkrumah University of Science and Technology. This has led to the conversion of other LULC types into urban/built-up areas. However, the least urban expansion that occurred in the Manhyia sub-metropolitan zone may be linked to the traditional controls restricting the indiscriminate conversion of other LULC into urban/built-up areas.

The projected map confirmed that urban/built-up areas will dominate the other LULC classes, agreeing with work on other areas of Ghana including the research of $[20,33,38]$. From 2013 to 2015, a substantial 448 hectares were added to the urban-built-up areas which vindicated the use of the 2013 and 2015 satellite images.

\subsection{Effects of Urban Expansion}

It was observed that urban expansion led to losses in the natural landscape. Many green areas in Kumasi had undergone an intensive transformation from a recreational setting to an economic hub [64]. The major recreational areas have all witnessed changes in land use [41,65]. The agricultural lands in Kumasi were converted to urban/built-up areas (residential, commercial and industrial). Findings from this research are consistent with the works of [66], using Kunming city in China as a case study. According to [67], uncontrolled urban expansion of cities reduces agricultural land. Results from this work were in line with [39] who concluded that the land cover of Kumasi has undergone intense changes. Urban/built-up areas have gained more at the expense of agricultural and forestlands [33]. Our research also corroborates earlier findings, including [20,33], that the fate of urban agriculture and biodiversity could be at risk in Kumasi. According to [36], the increase in the urban/built-up areas in Kumasi has led to urban warming and thus has impacted the land surface temperature.

\section{Conclusions}

We utilized multi-temporal Landsat satellite imagery and other relevant datasets to track urban expansion in Kumasi from 1986 to 2015 and predicted future urban/built-up areas for 2025. This research not only examined the spatio-temporal changes using the RF classifier but also attempted to provide a deeper comprehension of the urban expansion of Kumasi.

This research concludes that the RF algorithm is a better classifier compared to the traditional parametric classifiers, based on its accuracy outputs. The evaluation of change detection, urban expansion in the sub-metropolitan zones, density decay curve, buffer creation, correlation analysis and the student T-test to test significance revealed that urban/built-up areas are continually increasing at the expense of the other LULC types. The study revealed that the increase in population and economic activities have affected LULC alterations. 
Urban land modeling using the Multi-Layer Perceptron and the Markov Chain which generated the future LULC map also predicted increased urban/built-up areas for 2025. It is expected that urban expansion may move beyond the boundaries of the Kumasi Metropolis into the adjacent satellite towns in the Ashanti Region. It is also concluded that, the infrastructural developments after 2013 and before 2015 had a significant impact on the green areas (agricultural and forestlands) in Kumasi.

The major limitation of our research was our inability to obtain suitable and appropriate Landsat satellite data for at least a 10-year interval for the required years, especially between 1986 and 2013 for the study area. The techniques adopted in this study for satellite image classification and urban expansion are considered straightforward. However, in our study, the 10-year interval was considered for the prediction for LULC 2025, with an emphasis on urban/built-up areas. Future works could also utilize RS data from the rainy season. Other machine learning classifiers such as Support Vector Machine and Artificial Neural Networks may also be incorporated for the classification of satellite images. Again, remote sensing indices could also be incorporated to provide further insights into the urban environment.

However, we propose that the city planners will inculcate vertical construction of buildings to avoid the wastage of agricultural and forestlands. This can be done in partnership with the Ministries of Housing, Agriculture and Forestry in Ghana. Again, the existing land-use policies ought to be enforced by the Kumasi Metropolitan Assembly. The consequences of uncontrolled urban expansion may include urban heat islands, continued loss of arable and natural areas and increased air pollution in the study area.

Our research provided gainful insights into spatio-temporal patterns and trends in urban/built-up areas using the state of the art machine learning classifier, Random Forests, an efficient technique used in tracking and predicting urban/built-up areas. This research can contribute to the existing framework for the development of land planning measures that promote the integration of other LULC types as urban-built up areas expand in cities.

Author Contributions: Conceptualization, B.F.F. and F.M. Data curation, B.F.F. Formal Analysis, B.F.F. Investigation, B.F.F. Methodology, B.F.F. and F.M. Project administration, B.F.F. and F.M. Resources, F.M. Software, F.M. Visualization, B.F.F. and F.M. Writing-original draft, B.F.F. Writing-review and editing, F.M. Supervision, F.M. All authors have read and agreed to the published version of the manuscript.

Funding: B.F.F. thanks the Katholischer Akademischer Ausländer-Dienst (KAAD) for the scholarship support for his PhD studies which has given birth to this research. Open Access publication was sponsored by Brandenburg University of Technology, Cottbus-Senftenberg.

Institutional Review Board Statement: Not applicable

Informed Consent Statement: Not applicable

Data Availability Statement: Data Availability Statements in section “MDPI Research Data Policies" at https: / / www.mdpi.com/ethics.

Acknowledgments: The authors are grateful to the USGS for the cost-free satellite images and Digital Elevation Model of Kumasi. We thank the three anonymous reviewers and the editor for their very useful comments on the previously submitted manuscript. We thank the entire EuroAquae family in Cottbus especially Ing Qianwen He, Nora, Manh and Fritzi and the entire staff at the Department of Hydrology-Brandenburg University of Technology, Cottbus-Senftenberg for their unflinching support. We are also grateful to Isaac Mbir Bryant (Ph.D.), Frederick Gyasi Damptey, Louis Okofo Boansi, Opoku Fosu (Senior \& Junior) and Rhoda Bema Boateng for their diverse assistance.

Conflicts of Interest: The authors declare no conflict of interest. 


\section{Appendix A. User and Producer Accuracies for the Classified Satellite Images}

Table A1. User, Producer and Kappa statistics for the classified image of 1986.

\begin{tabular}{ccccccc}
\hline LULC & Urban/Built-Up & Agricultural Lands & Forestlands & Total & User Accuracy & Kappa \\
\hline Urban/built-up & 50 & 0 & 0 & 50 & 1 & 0 \\
Agricultural lands & 8 & 42 & 0 & 50 & 0.84 & 0.88 \\
Forestlands & 6 & 0 & 44 & 50 & 0 & 0 \\
Total & 64 & 42 & 44 & 150 & 0 & 0 \\
Producer Accuracy & 0.78 & 1 & 0 & 0 & 0 & 0.86 \\
Kappa & 0 & 0 &
\end{tabular}

Table A2. User, Producer and Kappa statistics for the classified image of 2013.

\begin{tabular}{ccccccc}
\hline LULC & Urban/ Built-Up & Agricultural Lands & Forestlands & Total & User Accuracy & Kappa \\
\hline Urban/built-up & 50 & 0 & 0 & 50 & 1 & 0 \\
Agricultural lands & 0 & 50 & 0 & 50 & 0 & 0.92 \\
Forestlands & 1 & 3 & 46 & 50 & 0 & 0 \\
Total & 51 & 53 & 1 & 0 & 0.97 & 0 \\
Producer Accuracy & 0.98 & 0.94 & 0 & 0 & 0.96 \\
Kappa & 0 & 0 & &
\end{tabular}

Table A3. User, Producer and Kappa statistics for the classified image of 2015.

\begin{tabular}{ccccccc}
\hline LULC & Urban/ Built-Up & Agricultural Lands & Forestlands & Total & User Accuracy & Kappa \\
\hline Urban/built-up & 50 & 0 & 0 & 50 & 1 & 0 \\
Agricultural lands & 2 & 48 & 0 & 50 & 0.96 & 0.98 \\
Forestlands & 1 & 0 & 49 & 50 & 0 & 0 \\
Total & 53 & 48 & 49 & 150 & 0 & 0.98 \\
Producer Accuracy & 0.94 & 1 & 0 & 0 & 0 & 0.97 \\
Kappa & 0 & 0 & 0 & 0 \\
\hline
\end{tabular}

\section{Appendix B. Student $t$-test}

Student $t$-test: Two samples assuming unequal variance

$\mathrm{H}_{\mathrm{O}}: \mathrm{r}=0$

$\mathrm{H}_{\mathrm{a}}: \mathrm{r} \neq 0$

For $400 \mathrm{~m}$, number of buffers $=10$

$\mathrm{r}=$ Correlation between Density of Urban Expansion and the Distance to the main $\operatorname{road}(0.75)$.

Using the $400 \mathrm{~m}$ buffer, $(\alpha=0.05$, degrees of freedom, $\mathrm{n}-2=8)$.

$$
t_{\mathrm{ob}}=\mathrm{r} \sqrt{\frac{\mathrm{n}-2}{1-\mathrm{r}^{2}}} \mathrm{t}_{\mathrm{ob}}=0.75 \sqrt{\frac{10-2}{1-(0.75)^{2}}} \mathrm{t}_{\mathrm{ob}}=3.2
$$

The observed $t\left(t_{\mathrm{ob}}\right)$ and the critical $\left(t_{\text {crit }}\right)$ at the significance level alpha $=0.05 ; t_{\text {crit }}$ for $400 \mathrm{~m}=2.31$ was compared.

The correlation was significant since $t_{\mathrm{ob}}(3.2)>\mathrm{t}_{\mathrm{crit}}(2.31)$, thus $\mathrm{H}_{\mathrm{O}}$ was rejected.

\section{References}

1. United Nations Department of Economic and Social Affairs-Population Division (UNDESA-PD). World Population Prospects 2019-Highlights; United Nations: New York, NY, USA, 2019.

2. United Nations Department of Economic and Social Affairs-Population Division (UNDESA-PD). The 2018 Revision. In World Urbanization Prospects; United Nations: New York, NY, USA, 2019; Volume 12. 
3. Martine, G.; McGranahan, G.; Montgomery, M.; Fernández-Castilla, R. The New Global Frontier: Urbanization, Poverty and Environment in the 21st Century; Earthscan: London, UK, 2012.

4. Moriconi-Ebrard, F.; Harre, D.; Heinings, P. Urbanisation Dynamics in West. Africa 1950-2010: Africapolis I, 2015 Update; West African Studies, OECD Publishing: Paris, France, 2016.

5. Raddad, S.; Salleh, A.G.; Samat, N. Determinants of Agriculture Land Use Change in Palestinian Urban Environment: Urban Planners at Local Governments Perspective. Am. J. Sustain. Agric. 2010, 4, 30-38.

6. Patino, J.E.; Duque, J.C. A Review of Regional Science Applications of Satellite Remote Sensing in Urban Settings. Comput. Environ. Urban. Syst. 2013, 37, 1-17. [CrossRef]

7. Weeks, J.R. Population: An Introduction to Concepts and Issues, 10th ed.; Caldeira, C., Weeks, D., Beesley, T., Eds.; Thomson Wadsworth: Belmont, CA, USA, 2008.

8. Laurance, W.F.; Sayer, J.; Cassman, K.G. Agricultural Expansion and Its Impacts on Tropical Nature. Trends Ecol. Evol. 2014, 29, 107-116. [CrossRef]

9. Willcock, S.; Phillips, O.L.; Platts, P.J.; Swetnam, R.D.; Balmford, A.; Burgess, N.D.; Ahrends, A.; Bayliss, J.; Doggart, N.; Doody, K.; et al. Land Cover Change and Carbon Emissions over 100 Years in an African Biodiversity Hotspot. Glob. Chang. Biol. 2016, 22, 2787-2800. [CrossRef] [PubMed]

10. Parnell, S.; Walawege, R. Sub-Saharan African Urbanisation and Global Environmental Change. Glob. Environ. Chang. 2011, 21, S12-S20. [CrossRef]

11. Cohen, B. Urbanization in Developing Countries: Current Trends, Future Projections, and Key Challenges for Sustainability. Technol. Soc. 2006, 28, 63-80. [CrossRef]

12. International Panel on Climate Change (IPCC). Climate Change 2001: Impacts, Adaptation, and Vulnerability. Choice Rev. Online 2001, 39, 3433.

13. Ghana Statistical Service (GSS). 2010 Population \& Housing Census National Analytical Report. Ghana Stat. Serv. 2013, 1, 1-91.

14. Songsore, J. Towards a Better Understanding of Urban. Change: Urbanization, National Development and Inequality in Ghana; Ghana Universities Press: Accra, Ghana, 2003.

15. Owusu, G. Small Towns in Ghana: Justifications for Their Promotion under Ghana's Decentralisation Programme. Afr. Stud. Q. 2005, 8, 48-69.

16. GSS. 2010 Population and Housing Census, Summary of Report of Final Results. Ghana Stat. Serv. 2012, 1, 1-117.

17. Ghana Statistical Service (GSS). District Analytical Report. Kumasi Metropolitan; Sakoa Press Limited: Accra, Ghana, 2014.

18. Japan International Cooperation Agency (JICA). The Study on the Comprehensive Urban. Development Plan. for Greater Kumasi in the Republic of Ghana-Final Report Summary; Japan International Cooperation Agency: Tokyo, Japan; Oriental Consultants Co., Ltd.: Tokyo, Japan; CTI Engineering International Co., Ltd.: Tokyo, Japan; ALMEC Corporation: Tokyo, Japan, 2013.

19. Afrane, S.C.; Amoako, C. Peri-Urban development in Kumasi. In Future of the Tree: Towards Growth and Development of Kumasi; Adarkwa, K.K., Ed.; University Printing Press: Kumasi, Ghana, 2011; pp. 92-110.

20. Abass, K.; Adanu, S.K.; Agyemang, S. Peri-Urbanisation and Loss of Arable Land in Kumasi Metropolis in Three Decades: Evidence from Remote Sensing Image Analysis. Land Use Policy 2018, 72, 470-479. [CrossRef]

21. Afriyie, K.; Abass, K.; Adomako, J.A.A. Urbanisation of the Rural Landscape: Assessing the Effects in Peri-Urban Kumasi. Int. J. Urban. Sustain. Dev. 2014, 6, 1-19. [CrossRef]

22. Araya, Y.H.; Cabral, P. Analysis and Modeling of Urban Land Cover Change in Setúbal and Sesimbra, Portugal. Remote Sens. 2010, 2, 1549-1563. [CrossRef]

23. Frimpong, B.F. Land Use and Cover Changes in the Mampong Municipality of the Ashanti Region. Master's Thesis, Department of Theoretical and Applied Biology, Kwame Nkrumah University of Science and Technology, Kumasi, Ghana, 2015.

24. Vermeiren, K.; Van Rompaey, A.; Loopmans, M.; Serwajja, E.; Mukwaya, P. Urban Growth of Kampala, Uganda: Pattern Analysis and Scenario Development. Landsc. Urban. Plan. 2012, 106, 199-206. [CrossRef]

25. Aduah, M.S.; Baffoe, P.E. Remote Sensing for Mapping Land-Use/Cover Changes and Urban Sprawl in Sekondi-Takoradi, Western Region of Ghana. Int. J. Eng. Sci. 2013, 2, 66-73.

26. Schubert, H.; Calvo, A.C.; Rauchecker, M.; Rojas-Zamora, O.; Brokamp, G.; Schütt, B. Article Assessment of Land Cover Changes in the Hinterland of Barranquilla (Colombia) Using Landsat Imagery and Logistic Regression. Land 2018, 7, 152. [CrossRef]

27. Ross, C.; Fildes, S.; Millington, A.C. Land-Use and Land-Cover Change in the Páramo of South-Central Ecuador, 1979-2014. Land 2017, 6, 46. [CrossRef]

28. Taubenbock, H.; Esch, T. Remote Sensing-An Effective Data Source for Urban Monitoring. Available online: http:/ Earthzine. Org./2011/07/02/remote-sensing-an-effective-data-source-for-urban-monitoring/ (accessed on 9 November 2015).

29. Subedi, P.; Subedi, K.; Thapa, B. Application of a Hybrid Cellular Automaton-Markov (CA-Markov) Model in Land-Use Change Prediction: A Case Study of Saddle Creek Drainage Basin, Florida. Appl. Ecol. Environ. Sci. 2013, 1, 126-132. [CrossRef]

30. Attua, E.M.; Fisher, J.B. Historical and Future Land-Cover Change in a Municipality of Ghana. Earth Interact. 2011, 15, 1-26. [CrossRef]

31. Addae, B.; Oppelt, N. Land-Use/Land-Cover Change Analysis and Urban Growth Modelling in the Greater Accra Metropolitan Area (GAMA), Ghana. Urban. Sci. 2019, 3, 26. [CrossRef]

32. Yao, F.; Hao, C.; Zhang, J. Simulating Urban Growth Processes by Integrating Cellular Automata Model and Artificial Optimization in Binhai New Area of Tianjin, China. Geocarto Int. 2016, 31, 612-627. [CrossRef] 
33. Koranteng, A.; Zawia-nied, T. Monitoring of Deforestation in Kumasi Area (Ghana) by Satellite-Based Multi-Temporal Land Use Analysis Monitoring. Ann. Geomat. 2008, 6, 71-84.

34. Wemegah, C.S.; Yamba, E.I.; Aryee, J.N.A.; Sam, F.; Amekudzi, L.K. Assessment of Urban Heat Island Warming in the Greater Accra Region. Sci. Afr. 2020, 8, e00426.

35. Yeboah, F.; Awotwi, A.; Forkuo, E.K.; Kumi, M. Assessing Land Use and Land Cover Changes Due to Urban Growth in Accra. J. Basic Appl. Res. Int. 2017, 22, 43-50.

36. Mensah, C.; Atayi, J.; Kabo-Bah, A.T.; Švik, M.; Acheampong, D.; Kyere-Boateng, R.; Prempeh, N.A.; Marek, M.V. Impact of Urban Land Cover Change on the Garden City Status and Land Surface Temperature of Kumasi. Cogent Environ. Sci. 2020, 6, 1787738. [CrossRef]

37. Buo, I.; Sagris, V.; Burdun, I.; Uuemaa, E. Estimating the Expansion of Urban Areas and Urban Heat Islands (UHI) in Ghana: A Case Study. Nat. Hazards 2020. [CrossRef]

38. Owusu, A.B. An Assessment of Urban Vegetation Abundance in Accra Metropolitan Area, Ghana: A Geospatial Approach. J. Environ. Geogr. 2018, 11, 37-44. [CrossRef]

39. Koranteng, A. Competitive Land Use/Cover of Kumasi and Its Environs Based on Satellite Imagery Studies; ICAST: Orlando, FL, USA, 2014; pp. 208-219.

40. Essel, B. Depletion of Urban Green Space and Its Adverse Effect: A Case of Kumasi, the Former Garden City of West-Africa. J. Environ. Ecol. 2017, 8, 1. [CrossRef]

41. Mensah, C.A. Is Kumasi Still a Garden City? Land Use Analysis between 1980-2010. J. Environ. Ecol. 2014, 5, 89. [CrossRef]

42. Koranteng, A.; Zawiła-Niedźwiecki, T.; Kombat, D. Land Use Dynamics in Rural-Urban Environs: A Study of the Kumasi Metropolis and Its Adjoining Districts-Ghana. Teledetekcja Sr. 2015, 52, 67-85.

43. Abass, K.; Afriyie, K.; Abrafi Adomako, J.A. Household Responses to Livelihood Transformation in Peri-Urban Kumasi. J. Sustain. Dev. 2013, 6, 121-136. [CrossRef]

44. Cobbinah, P.B.; Amoako, C. Urban Sprawl and the Loss of Peri-Urban Land in Kumasi, Ghana. Int. J. Soc. Hum. Sci. 2012, $6,388-397$.

45. Nero, B.F.; Callo-Concha, D.; Anning, A.; Denich, M. Urban Green Spaces Enhance Climate Change Mitigation in Cities of the Global South: The Case of Kumasi, Ghana. Procedia Eng. 2017, 198, 69-83. [CrossRef]

46. Asabere, S.B.; Acheampong, R.A.; Ashiagbor, G.; Beckers, S.C.; Keck, M.; Erasmi, S.; Schanze, J.; Sauer, D. Urbanization, Land Use Transformation and Spatio-Environmental Impacts: Analyses of Trends and Implications in Major Metropolitan Regions of Ghana. Land Use Policy 2020, 96, 104707. [CrossRef]

47. Baboo, D.S.S.; Devi, M.R. An Analysis of Different Resampling Methods in Coimbatore, District. Glob. J. Comput. Sci. Technol. 2010, 10, 61-66.

48. Anderson, J.R.; Hardy, E.E.; Roach, J.T.; Witmer, R.E. A Land Use and Land Cover Classification System for Use with Remote Sensor Data; A Revision of the Land Use Classification System as Presented in U.S. Geological Survey Circular 671; United States Government Printing Office: Washington, DC, USA, 1976; p. 964.

49. Breiman, L. Random Forests. In Machine Learning; Academic Publishers: Cambridge, MA, USA, 2001; Volume 45, pp. 5-32.

50. Shade, C.; Kremer, P. Predicting Land Use Changes in Philadelphia Following Green Infrastructure Policies. Land 2019, 8, 28. [CrossRef]

51. Han, H.; Yang, C.; Song, J. Scenario Simulation and the Prediction of Land Use and Land Cover Change in Beijing, China. Sustainability 2015, 7, 4260-4279. [CrossRef]

52. Pontius, R.G., Jr.; Chen, H. GEOMOD Modeling. In Idrisi 15: The Andes Edition; Clark University: Worcester, MA, USA, 2006; pp. 1-44.

53. McLeod, S.; Schapper, J.H.M.; Curtis, C.; Graham, G. Conceptualizing Freight Generation for Transport and Land Use Planning: A Review and Synthesis of the Literature. Transp. Policy 2019, 74, 24-34. [CrossRef]

54. Deng, J.S.; Wang, K.; Hong, Y.; Qi, J.G. Spatio-Temporal Dynamics and Evolution of Land Use Change and Landscape Pattern in Response to Rapid Urbanization. Landsc. Urban. Plan. 2009, 92, 187-198. [CrossRef]

55. Kim, H.J. Spatiotemporal Pattern Analysis of Rapid Urban Expansion Using GIS and Remote Sensing. Int. J. Appl. Geospatial Res. 2010, 1, 55-70. [CrossRef]

56. Stemn, E.; Agyapong, E. Assessment of Urban Expansion in the Sekondi-Takoradi Metropolis of Ghana Using Remote-Sensing and GIS Approach. Int. J. Sci. Technol. 2014, 3, 452-460.

57. Eastman, J.R. TerrSet Tutorial; Clark Labs, Clark University: Worcester, MA, USA, 2016.

58. Chan, J.C.W.; Paelinckx, D. Evaluation of Random Forest and Adaboost Tree-Based Ensemble Classification and Spectral Band Selection for Ecotope Mapping Using Airborne Hyperspectral Imagery. Remote Sens. Environ. 2008, 112, 2999-3011. [CrossRef]

59. Shang, X.; Chisholm, L.A. Classification of Australian Native Forest Species Using Hyperspectral Remote Sensing and MachineLearning Classification Algorithms. IEEE J. Sel. Top. Appl. Earth Obs. Remote Sens. 2014, 7, 2481-2489. [CrossRef]

60. Skinner, M.W.; Kuhn, R.G.; Joseph, A.E. Agricultural Land Protection in China: A Case Study of Local Governance in Zhejiang Province. Land Use Policy 2001, 18, 329-340. [CrossRef]

61. Cities Alliance. Future Proofing Cities Metropolitan Cities in Ghana; Arup: London, UK, 2016.

62. Ghana Statistical Service (GSS). Urbanisation. 2010 Population \& Housing Census Report; Sakora Press Limited: Accra, Ghana, 2014.

63. Ministry of Environment, Science and Technology National Science, Technology and Innovation Policy; MESTI: Accra, Ghana, 2015. 
64. Asare, G.E. Kumasi: The Garden City without Gardens? Daily Graphic. Graphic Communications Group, Accra. pp. 40-41. Available online: http:/ / graphic.com.gh/features/features/10748-kumasi-the-garden-city-without-gardens.html (accessed on 4 January 2021).

65. Mensah, C.A. Destruction of Urban Green Spaces: A Problem Beyond Urbanization in Kumasi City (Ghana). Am. J. Environ. Prot. 2014, 3, 1. [CrossRef]

66. Zhou, X.; Wang, Y.C. Spatial-Temporal Dynamics of Urban Green Space in Response to Rapid Urbanization and Greening Policies. Landsc. Urban. Plan. 2011, 100, 268-277. [CrossRef]

67. Brueckner, J.K. U Rban S Prawl. Int. Reg. Sci. Rev. 2000, 23, 160-171. [CrossRef] 